УДК 316.7-057.17:378.018.43

DOI: https://doi.org/10.31866/2616-7573.1.2019.170660

\author{
ГРИГОРЧУК Тарас Васильович, \\ кандидат педагогічних наук, доцент, \\ Київський національний університет культури і мистецтв, \\ Київ, Україна, hryh@ukr.net \\ ORCID ID: https://orcid.org/0000-0002-0395-1966
}

\title{
ДИСТАНЦІЙНЕ НАВЧАННЯ У ПРОФЕСІЙНІЙ ПІДГОТОВЦІ МЕНЕДЖЕРІВ СОЦІОКУЛЬТУРНОЇ СФЕРИ
}

Анотація. Актуальність. Сьогодні навчальні інституції активно впроваджують засоби дистанційного навчання. Ці рішення забезпечують доступність навчальної інформації та зручність ії отримання. Не використовувати дані засоби - означає залишатися на узбіччі прогресу. Мета і методи. Мета статті полягає у виявленні можливостей використання засобів дистанційного навчання майбутніх менеджерів з урахуванням специфіки соціокультурної сфери. Нами використано емпіричний і системний підходи, методи аналізу та синтезу, згідно з якими запропоновано структуру навчально-методичного комплексу для дистанційного навчання у взаємозв'язку його основних елементів і виокремленні специфічних чинників, важливих для підготовки менеджерів соціокультурної сфери. Результати. Основні результати дослідження полягають у виявленні передумов і доведенні необхідності застосування елементів дистанційного навчання у процесі підготовки фахівців-управлінців для забезпечення їхньої максимальної адаптивності до умов навчання та подальшої реалізації набутих компетентностей. Висновки та обговорення. Використання засобів дистанційного навчання забезпечує доступність знань, комфортність їх одержання і нічим не поступається іншим формам навчання. Надалі розглядатимуться питання методики розробки навчальних матеріалів для дистанційного навчання. Наукова новизна результатів у тому, що вперше висунуто структуру навчальнометодичного комплексу з урахуванням специфіки діяльності менеджера соціокультурної сфери; одержано подальший розвиток рішення щодо застосування модульної системи у професійній підготовці фахівців. Практичне значення полягає в можливостях застосування наших пропозицій у підготовці менеджерів сфери послуг.

Ключові слова: дистанційне навчання, навчально-методичний комплекс для дистанційного навчання, інтерактивне навчальне середовище, рейтингові бали, навчальний модуль.

Григорчук Тарас Васильевич, кандидат педагогических наук, доцент, Киевский национальный университет культуры и искусств, Киев, Украина

\section{Дистанционное обучение в профессиональной подготовке менеджеров социокультурной сферы}

Аннотация. Актуальность. Сегодня учебные институты активно внедряют средства дистанционного обучения. Эти решения обеспечивают доступность учебной информации и удобство ее получения. Не использовать данные средства значит оставаться на обочине прогресса. Цель и методыл. Цель статьи заключается в выявлении возможностей использования средств дистанционного обучения 
будущих менеджеров с учетом специфики социокультурной сферы. Нами использованы эмпирический и системный подходы, методы анализа и синтеза, согласно которым предложена структура учебно-методического комплекса для дистанционного обучения во взаимосвязи его основных элементов и выделении специфических факторов, важных для подготовки менеджеров социокультурной сферы. Результатыл. Основные результаты исследования заключаются в выявлении предпосылок и доведении необходимости применения элементов дистанционного обучения в процессе подготовки специалистов-управленцев для обеспечения их максимальной адаптивности к условиям обучения и дальнейшей реализации приобретенных компетенций. Выводы и обсуждение. Использование средств дистанционного обучения обеспечивает доступность знаний, комфортность их получения и ничем не уступает другим формам обучения. В дальнейшем будут рассматриваться вопросы методики разработки учебных материалов для дистанционного обучения. Научная новизна в том, что впервые выдвинуто структуру учебно-методического комплекса с учетом специфики деятельности менеджера социокультурной сферы; получено дальнейшее развитие решения о применении модульной системы в профессиональной подготовке специалистов. Практическое значение состоит в возможностях применения наших предложений в подготовке менеджеров сферы услуг.

Ключевые слова: дистанционное обучение, учебно-методический комплекс для дистанционного обучения, интерактивная учебная среда, рейтинговые баллы, учебный модуль.

Hryhorchuk Taras, PhD (Pedagogic), Associate Professor, Kiev National University of Culture and Arts, Kiev, Ukraine

Distant learning in professional training of the socio-cultural sphere managers'

Abstract. Actuality. Today, educational institutions are actively implementing distance learning tools. These solutions provide the availability of educational information and the convenience of obtaining it. Do not use these tools means staying on the sidelines of progress. Purpose and methods. The purpose of the paper is to identify the possibilities of using distance learning tools for future managers, taking into account the specifics of the socio-cultural sphere. We used empirical and systematic approaches, methods of analysis and synthesis, according to which the structure of the teaching-methodical complex for distance learning was proposed in the interconnection of its main elements and the identification of specific factors important for the preparation of managers of the socio-cultural sphere. Results. The main results of the study are to identify the prerequisites and prove the need to use the elements of distance learning in the process of training specialists-managers to ensure their maximum adaptability to the conditions of training and further implementation of the acquired competencies. Conclusions and discussion. The use of distance learning tools ensures the availability of knowledge, the comfort of their obtaining and are not inferior to other forms of learning. In the future, the methodology for the development of teaching materials for distance learning will be considered. The scientific novelty of the results is that for the first time the structure of the educationalmethodical complex was introduced, taking into account the specifics of the activity of the manager of the socio-cultural sphere; further developed a decision on the application of the modular system in the professional training of specialists. The practical value lies in the possibility of applying our suggestions in the training of service managers.

Keywords: distance learning, distance education training system, interactive learning environment, rating points, curriculum module. 


\section{1. Актуальність проблеми Actuality of problem}

Всім сучасникам є очевидним той факт, що успіх людини, фірми, організації, країни напряму залежать від уміння належним чином інтегруватися в товариство, спільноту, світ, а далі показати такі якості, які сприятимуть подальшій активній еволюції в зазначених середовищах. Кожна спільнота на всіх рівнях формує набори критеріїв, відповідно до яких визначається придатність їі учасників до перебування в ній. Тобто, країни, підпорядковані диктаторській системі управління, не мають змоги потрапити до табору демократичних суспільств; підприємства, керовані директивно, не зможуть проникнути до еліти світового бізнесу; спеціалісти, які нездатні використовувати новітні технології для роботи та самовдосконалення, не посядуть значних конкурентних позицій на ринку праці.

Сьогодні питання підготовки фахівця, здатного боротися за своє робоче місце, напряму пов'язане з розвитком методик і технологій, що превалюють у конкретний момент історичного розвитку. Очевидно, що передача основної маси навчальної інформації здійснюється з активним використанням інформаційно-комунікаційних технологій і сформованих на цій основі методик, які все частіше доповнюють, а нерідко й замінюють традиційні методи підготовки професіоналів-управлінців. Такий стан справ зумовлює необхідність постійного оновлення знань, що вимагає активного використання вказаних технологій у процесі підготовки конкурентоспроможних фахівців соціокультурної сфери.

Стан вивчення проблеми. Впровадження інформаційно-комунікаційних технологій у сучасні навчальні системи, психолого-педагогічні аспекти та методики створення дистанційних курсів навчальних дисциплін досліджували чимало вчених. Зокрема, Ю. Богачков (2004) присвятив свої роботи дослідженню систем діагностики рівня засвоєння знань студентів у дистанційному навчанні. Цей вчений розробив значну кількість методик проведення тестового контролю знань студентів. Дж. Керслі (Kearsley, 1995), один із піонерів і активних пропагандистів дистанційного навчання, розглядав особливості включення дистанційного навчання до традиційної системи навчання. Він один із перших здійснив глибокий аналіз ефективності дистанційного навчання як засобу одержання знань і довів його беззаперечну ефективність. У працях Н. Морзе (2005) розглянуто підходи щодо підготовки викладачів до роботи в системі дистанційного навчання.

Питання організації дистанційного навчання також активно досліджувалося вченими. Так, у працях Р. Бендера (Bender, 1995) чи не вперше виникла ідея формування інтернет-спільнот для вивчення тих чи інших навчальних дисциплін. Як бачимо, сьогодні - це основа одержання 
навчальної інформації з електронних мереж і передумова формування мереж соціальних, які також активно використовуються в навчальному процесі. В. Олійник (2007) активно досліджує особливості методик використання дистанційного навчання у післядипломній освіті. Вчений активно відстоює позиції дистанційного навчання особливо для одержання навчальної інформації дорослими людьми, зайнятими професійною діяльністю. У працях Б. Уілліса (Willis, 1997) зроблено акцент на практичну значимість дистанційного навчання, тобто можливість одержувати знання комфортно, зручно за найбільш вигідних умов щодо часу, місця тощо. Практично, дослідник доводить беззаперечні переваги дистанційного навчання як для того, хто навчається, так і для того, хто навчає.

Відповідно до теми нашого дослідження нас цікавлять доробки в царині представлення управлінських дисциплін. Тут серед відомих дослідників і розробників інноваційних навчальних засобів із менеджменту та маркетингу ми виявили, зокрема, праці Д. Гансена (Hansen, 2008), який зосередив свою дослідницьку активність довкола проблеми передачі знання в середовищі дистанційного навчання. Доробок вченого також полягає в тому, що він запропонував більш широкий спектр носіїв знань у дистанційному навчанні, а саме, долучив до нього експертів і практиків бізнесу, в яких можна одержати навчальну інформацію. Л. Харман (Harman, 2009) присвятив свої роботи можливостям навчання студентів дистанційної форми стратегічному підходу в організації партнерської взаємодії в бізнесі. При цьому сама форма дистанційного навчання подавалася як партнерська взаємодія.

Невирішені питання. Насправді невирішених питань щодо впровадження дистанційного навчання $є$ значно більше, ніж вже вирішених. Ми зупинимось лише на кількох із них. Насамперед дистанційне навчання у процесі підготовки професіонала не завжди коректно вписується в ухвалені моделі випускника вищої школи дуже багатьох країн світу, що ускладнює належну оцінку компетентнісних даних при, наприклад, зарахуванні на роботу. 3 іншого боку, методологічна недосконалість створення багатьох курсів навчальних дисциплін для дистанційного навчання формує передумови для активного відстоювання аудиторної форми навчання як найбільш надійної. Наступним важливим чинником залишається питання адекватної оцінки й оплати праці науково-педагогічного працівника, задіяного у процесі розробки, викладання навчальних курсів у режимі дистанційного навчання та безпосередньої оцінки його результатів. I водночас практично не зустрічаються праці дослідників щодо організації дистанційного навчання фахівців, задіяних у соціокультурній сфері. А це, своєю чергою, могло б сприяти вирішенню чималої кількості макро- та мікроекономічних проблем, пов'язаних із кадровим забезпеченням інституцій культури, мистецтв і шоу-бізнесу. 


\section{2. Мета і методи дослідження Purpose and methods of research}

Мета статті - виявлення місця засобів дистанційного навчання у процесі професійної підготовки конкурентоспроможних менеджерів, які активно і кваліфіковано діятимуть у соціокультурній сфері.

Методологічною основою дослідження $\epsilon$ сформовані на сьогодні теоретичні дані щодо успішного застосування засобів дистанційного навчання в підготовці кваліфікованих працівників для різних сфер підприємницької діяльності. Сам процес дослідження базується на перманентній основі його проведення, оскільки ми тією чи іншою мірою використовуємо методи дистанційного навчання у повсякденній педагогічній практиці. Зокрема, у автора є власний сайт, наповнений навчальною та допоміжною інформацією, де студенти мають змогу ознайомитися 3 лекційним матеріалом, перевірити одержані знання, пройшовши тестування, перейти за посиланнями на сторінки бізнес-асоціацій, експертів, наукових співтовариств. Вказані підходи створюють особливі сприятливі умови для одержання студентами як поточної навчальної інформації, сформованої відповідно до навчальних планів і робочих навчальних програм, так і ознайомлення із сучасним станом навчальних проблем, виявлення незрозумілих питань для обговорення їх на навчальних заняттях. При цьому найбільш важливим у нашому дослідженні залишалося належне застосування моделей реалізації управлінських знань різних галузей, висвітлених у лекційному матеріалі чи одержаних із зовнішніх джерел від експертів чи безпосередніх бізнесменів-практиків, через їх адаптацію до специфіки соціокультурної діяльності.

Методи дослідження. У дослідженні використано емпіричний і системний підходи, методи аналізу та синтезу, згідно з якими запропоновано структуру навчально-методичного комплексу для дистанційного навчання у взаємозв'язку його основних елементів і виокремленні специфічних чинників, важливих для підготовки менеджерів соціокультурної сфери. В окремих напрямах дослідження використано методи індукції та дедукції, що забезпечило можливості для належної фрагментації чинників для виявлення передумов щодо необхідності впровадження окремих елементів дистанційного навчання майбутніх менеджерів соціокультурної сфери й виявлення прогнозування вагомості цього виду підготовки запитаних ринком кваліфікованих фахівців.

Інформаційна база дослідження. Основою одержаних нами даних $\epsilon$ опрацювання результатів досліджень провідних вчених і дослідників дистанційного навчання. При цьому аналізу були піддані як дані, що показали дистанційне навчання як перспективну сферу поширення актуальної навчальної інформації, так і ті з них, що до цієї форми навчання ставляться негативно. При цьому нами бралися до уваги результати 
діяльності наукових і навчальних інституцій різних країн, які на практиці активно використовують можливості дистанційного навчання; думки осіб, які навчаються дистанційно; окремих експертів і працедавців. У процесі дослідження використані також дані особистих спостережень автора, здійснених під час викладання професійно-орієнтованих дисциплін за спеціальністю «Менеджмент соціокультурної діяльності» в Київському національному університеті культури і мистецтв.

\section{3. Результати дослідження Research results}

Науково-педагогічний працівник, який зайнятий у викладанні професійно-орієнтованих навчальних дисциплін, $\epsilon$ початковою ланкою поєднання студента 3 його майбутньою професійною діяльністю. Це визнана аксіома і не підлягає жодним науковим дебатам. Водночас у який спосіб надається навчальна інформація викладачем - питання 3 шуканою відповіддю. Найбільш простим методом ознайомлення з процесом донесення навчальної інформації $є$ вивчення навчально-методичного комплексу конкретної навчальної дисципліни.

Розробка навчально-методичних матеріалів - неодмінна умова професійної діяльності науково-педагогічного працівника. Ця обставина зумовлена цілим рядом чинників, серед яких: відхід від домінування ідеології; вимоги щодо здійснення ліцензування та акредитації ВНЗ; швидкоплинність суспільно-економічного розвитку; кардинальні зміни технологій; звужена диференціація замовлень щодо конкретних типів спеціалістів; зорієнтованість на компетентності; зміни вподобань і професійної спрямованості осіб, які навчаються, та багато інших. Відповідно до вказаних чинників практично кожен викладач ВНЗ часто змушений переглядати або й переробляти власні навчальні матеріали, основу яких становить навчально-методичний комплекс дисципліни (НМКД).

Очевидно, що у вітчизняній системі вищої освіти вже існують усталені підходи щодо формування НМКД для підготовки фахівцівуправлінців у соціокультурній діяльності, оскільки практично всі вони мають підпорядковуватися вимогам директивних документів, на основі яких розробляються внутрішні положення щодо вимог до їх оформлення. Незначні відмінності можуть бути зумовлені лише специфікою спеціальності, змістом окремої навчальної дисципліни або ж творчим потенціалом науково-педагогічного працівника. Базовий зразок НМКД обов'язково має включати вказані елементи:

- навчальна програма дисципліни;

- робоча навчальна програма з тематичним планом, планом занять, завданнями до іспиту (заліку), рекомендованою літературою тощо;

- конспект лекцій; 
- плани проведення практичних (семінарських) занять;

- вимоги й запитання до рубіжного та підсумкового контролю;

- завдання для самостійної роботи студентів;

- екзаменаційні білети;

- перелік рекомендованої літератури (інформаційних джерел).

Деякі навчальні заклади серед елементів НМКД передбачають наявність опорних конспектів, структурно-логічних схем навчального матеріалу, мультимедійних або інших презентацій, завдань для проходження практики тощо.

Однак, на нашу думку, при розробці моделі компетентнісно-орієнтованого НМКД із використанням елементів дистанційного навчання (НМКДДН) для викладання управлінських дисциплін вказаних вище елементів може бути недостатньо. Практично всі вони розраховані на роботу зі студентами за умов безпосереднього контакту викладача зі студентом або ж, у випадку роботи зі студентами заочної форми, під час надання науково-педагогічним працівником вихідних положень, джерел 3 інформаційними матеріалами й вимог щодо контролю знань у ході зустрічей на екзаменаційних сесіях. Більшість із них не мають особистісної зорієнтованості (Левшин, 2005). Основною навчальною метою таких НМКД є формування традиційних знань, умінь і навичок, а не професійних компетенцій, зорієнтованих на превалювання формування досвіду та активізації оперативного використання знань.

Подолання виявлених протиріч у загальнометодологічному сенсі, на нашу думку, стає можливим за умов використання в педагогічному проектуванні навчальних матеріалів практико-орієнтованих дисциплін, до яких відноситься менеджмент у соціокультурній діяльності, таксономії навчальних цілей. Модель, що переросла в когнітивну теорію таксономії навчальних цілей, була запропонована Б. Блумом, який виокремив шість таксономічних рівнів засвоєння навчальної інформації:

1) знання - запам'ятовування попередньо вивченого матеріалу;

2) розуміння - усвідомлення сутності вивченого матеріалу;

3) застосування - вміння користуватися матеріалом у нових ситуаціях;

4) аналіз - уміння розчленовувати ціле на складові елементи;

5) синтез - уміння створювати ціле з частин;

6) оцінювання - вміння визначати цінність і придатність певних засобів для досягнення поставленої мети (Малафіїк, 2005, с. 173-176).

3 іншого боку - корисним є підхід, запропонований Р. Жуковою та Ю. Кузнєцовим, які, розвиваючи теорію педагогічної системи В. Безпалька, виокремили п'ять рівнів навчання, що припускають синтез традиційних і нетрадиційних навчальних методів (Жукова \& Кузнецов, 1989):

1) знання-знайомства, які дозволяють студенту розрізняти, впізнавати знайомий йому предмет, явище, певну інформацію;

2) знання-копії, що дозволяють репродукувати засвоєну інформацію; 
3) знання-вміння, тобто можливість застосувати одержані знання у практичній діяльності;

4) знання-навички - певні автоматизовані вміння;

5) категорія творчості, результатом якої $є$ так звані дії «без правил» у певній галузі навчально-пізнавальної діяльності.

Використання таксономії Блума і наукових позицій Жукової та Кузнєцова у проектуванні НМКДДН є ще більш необхідним, оскільки навчальний процес відбувається за відсутності безпосереднього контакту між викладачем і студентом, що ускладнює педагогічний супровід тих, хто навчається. При цьому результати отриманих знань принаймні не повинні бути гіршими, ніж за традиційного навчання. Застосування вказаних підходів уможливлює формування відповідних навчальних цілей на кожному з етапів навчання та перестраховує викладача від можливих помилок. Їх дієвість підкріплюється ще й тим, що на цих засадах працюють провідні світові освітні інституції, вони лежать в основі більшості сучасних практико-орієнтованих навчальних технологій (Кухаренко, 2011).

Узагальнюючи результати діяльності навчальних закладів, задіяних у дистанційному навчанні фахівців-управлінців, і спираючись на власний досвід, ми вважаємо, що основним завданням НМКДДН є надання особам, які навчаються, засобів навчання й забезпечення організації самого процесу навчання у спосіб, що сприятиме формуванню відповідних фахових компетентностей. При цьому передбачається скорочення трудових затрат викладача на організацію процесу навчання, консультування і контролю шляхом забезпечення самостійної роботи студента через взаємодію з навколишнім ринковим середовищем, колегами й фахівцями, комп'ютером та іншими дидактичними засобами, придатними для досягнення заданого рівня компетентності. Однак рубіжний $\mathrm{i}$ підсумковий контроль залишається за викладачем, оскільки саме ці етапи визначають відповідальність за безпосередній рівень сформованості компетентностей. Більше того, ми є прихильниками проведення рубіжного контролю у традиційний спосіб, а за можливості, ще й проведення традиційних оглядових лекцій.

Водночас береться до уваги те, що:

1) студент у своїй професійній діяльності виконує певні управлінські функції в соціокультурній сфері або принаймні цікавиться ринковими процесами, самостійно отримує у такий спосіб власну інформацію;

2) частина засобів навчання може дублюватися і подаватися на різних носіях (книга, науково-популярна періодика, методична розробка тощо);

3) взаємодія студента з комп'ютерними мережами, а через них із викладачем може мати як рекомендаційний, так і обов'язковий характер залежно від етапу навчання та рівня засвоєння навчального матеріалу;

4) процес навчання припускає можливість спілкування студентів не тільки з викладачем, але й між собою, з іншими фахівцями та експертами. 
Зважаючи на вищевказане, стає очевидним, що НМКДДН з управлінських дисциплін використовуватиметься в інтерактивному навчальному середовищі (Григорчук \& Олійник, 2005, с. 74-80). Таке середовище забезпечує різноспрямовану навчальну взаємодію і сприяє формуванню суб'єктних відносин між учасниками навчального процесу (Григорчук, 2004 , с. 60). Саме ж інтерактивне навчальне середовище має вигляд, представлений на рис. 1.

В умовах компетентнісно-орієнтованого навчання інтерактивне навчальне середовище набуває особливого статусу, оскільки створює можливості для обміну між суб'єктами навчального процесу як навчальною інформацією, так і емпіричними даними щодо сучасного стану розвитку об'єктів наукового пізнання. Практично створюється можливість постійного самовдосконалення не тільки студентів, але й викладача шляхом моніторингу змін навколишнього середовища, який здійснюється на основі спостережень, консультування з провідними фахівцями та професійної практики студентів-дистанційників.

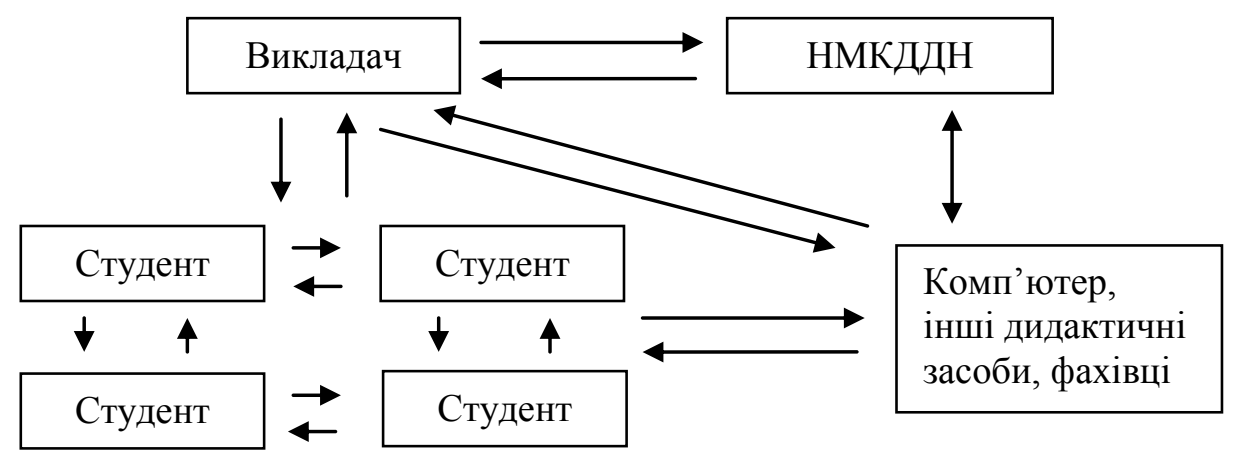

Рuc. 1. Схема інтерактивного навчального середовища Джерело: власна розробка

Fig. 1. Scheme of interactive learning environment Source: own development

У випадку, коли використання комп'ютера в навчальному процесі $\epsilon$ рекомендованим, слід брати до уваги когнітивні можливості комп'ютерноопосередкованого середовища. До них, зокрема, відносять: мультимедійні можливості, такі як звук, відео, комп'ютерна графіка й анімація; використання гіпертексту, сутність якого полягає в можливості надання людині засобів для сприймання інформації у визначуваній нею послідовності.

Однією з найважливіших ознак НМКДДН з управлінських дисциплін має бути принцип модульності, або за чітко визначеними розділами. Модульне навчання - це цілісна система, що інтегрує дидактичні засоби, необхідні для вирішення основних цілей освіти. Це означає, що увесь процес навчання має поділятися на навчальні модулі (розділи), кожен 3 
яких являє собою цілісний закінчений виклад певного навчального розділу (теми), передбачає варіанти контрольних завдань (контрольних робіт, курсових робіт або проектів) із курсу, словник основних термінів і понять, список інформаційних джерел тощо (Андрианова, 2004). Основними дидактичними засобами реалізації навчального модуля $є$ педагогічно адаптована система понять у вигляді сукупності системи знань, системи норм і системи цінностей. Крім того, це - поетапне суб'єктивне відкриття студентом під паритетним впливом викладача цієї системи у ході пошукової пізнавальної активності та подальшого її використання як засобу (способу) діяльності. Навчальний модуль активізує самостійну пізнавальну діяльність студентів, забезпечує іiї поетапну організацію, регулювання, контроль та оцінку (Кесаманлы, 1989, с. 121).

Об'єднуючими елементами НМКДДН виступають його зміст; вступна частина; інструктивний розділ, в якому наводяться підходи до правильного використання навчальних матеріалів; тематичний план навчальної дисципліни (за необхідності - календарний план); навчальна програма; завдання для підсумкового контролю; список інформаційних джерел, глосарій.

У комп'ютерно-опосередкованому мережному навчальному середовищі зміст НМКДДН являє собою структурований гіпертекстовий список основних його частин. Гіпертекстові можливості створюють додаткові комфортні умови для засвоєння знань. Студенти отримують можливість негайного переходу до запитаного навчального матеріалу, не гаючи часу на гортання сторінок чи звернення до пошукових систем. Зважаючи на зайнятість більшості студентів, які користуються дистанційною формою навчання в освоєнні управлінських знань, економія чи правильний розподіл часу можуть стати для них визначальним мотиваційним чинником щодо навчання загалом.

Iз точки зору компетентнісно-орієнтованого навчання пізнавальна діяльність людини пов'язана з уявленням результату, на досягнення якого вона спрямовує свої зусилля, на формування належних компетенцій. Тобто тут фахівець, який лише формується, завдяки наявності здібності до випереджаючого віддзеркалення дійсності створює уявний образ майбутнього результату, планує свою діяльність із його досягнення як із позиції засобів і методів, так і на основі передбачуваних затрат й оцінки якості очікуваного продукту. Це положення визначає необхідність наявності вступної частини комплексу.

Вступна частина комплексу має включати:

- виклад цілей вивчення навчального матеріалу;

- опис структури комплексу, його основного змісту та цільової аудиторії;

- вказівку на міжпредметні зв'язки або навчальні модулі, знання яких є необхідними для засвоєння даного комплексу. 
Інструктивні матеріали мають надавати студентам, які користуються дистанційним навчанням, пояснення щодо питань ефективного використання НМКДДН для досягнення планомірності та комплексності засвоєння навчального матеріалу. Тут же вказуються вимоги до організації навчального процесу, порядку проведення поточного та підсумкового контролю. Сюди ж можуть бути віднесені розрахунки рейтингових балів за видами поточного контролю.

Тематичний план - це розділ НМКДДН, де студент вперше бачить структуру навчального курсу, поділену на окремі модулі, теми. При цьому саме в тематичному плані відображено кількість навчального часу на вивчення як окремих тем, так і навчальних модулів загалом. Комп'ютерно-опосередковане навчальне середовище дає можливість викласти тематичний план у гіпертекстовому середовищі. А це, у свою чергу, забезпечує таке ж спрощення доступу до навчальних матеріалів, як і у випадку зі вступом.

Провідні навчальні заклади дистанційного навчання часто застосовують ще й календарний план. У такому плані вказуються часові межі вивчення окремих модулів, визначаються дати та час проходження тестувань, розробляються графіки представлення результатів практичних досліджень, письмових робіт тощо. Такий підхід заслуговує на увагу, оскільки в ньому присутня значна мотиваційна складова, яка спонукає студента своєчасно та якісно виконувати завдання.

Важливим об'єднуючим елементом НМКДДН є навчальна програма. У дистанційному навчанні іï функціональне призначення розширюється. Тут вона перестає бути простою базою навчальної дисципліни, в якій викладено інформаційну наповненість модулів і тем. Завдяки гіпертексту навчальна програма стає засобом навігації всім навчальним матеріалом. Студенти можугь отримати можливість для без перешкодного переходу до конкретного місця окремої теми.

Завдання для підсумкового контролю - розділ, основним завданням якого $\epsilon$ орієнтування студента на запланований навчальною дисципліною рівень компетенцій. Характерною ознакою цього розділу в дистанційному навчанні $\epsilon$ апелювання не лише до теоретичних знань та практичних навичок, а ще й до набутого досвіду, що $є$ важливою ознакою фахової компетенції. Тому формулювання завдань має передбачати порівняння, аналітику, систематизацію тощо.

Прийнятий у традиційних НМКД «Список рекомендованої літератури» у дистанційному навчанні зростає до списку інформаційних джерел. Цей перехід уможливлюється завдяки використанню сучасних інформаційних технологій, а особливо - мережі інтернет, завдяки чому студент може отримувати найсвіжішу теоретичну та практичну інформацію. Правильне компонування посилань на інформаційні джерела фактично долає наявну проблему «старіння» традиційного списку літератури. 
Глосарій або словник основних термінів і понять у дистанційному навчанні являє собою гіпертекстову сторінку, що спрямовує людину, яка навчається, до необхідного матеріалу. Найважливішою перевагою такого глосарію $\epsilon$ все та ж економія часу. Водночас виникає можливість спрямовувати відвідувачів до глосаріїв і словників, розміщених на інших сайтах.

Далі робота розпочинається над навчальними модулями (розділами), які у своїй органічній єдності являють собою електронний інтерактивний навчальний посібник із навчальної дисципліни (Григорчук \& Гушулей, 2004, с. 411-416).

Під електронним посібником ми розуміємо комплекс засобів навчання, що реалізовується в електронному вигляді, забезпечує вивчення навчальної дисципліни від певного початкового рівня підготовки студента до кінцевого рівня, діагностично-визначуваного через здатність студента відповідати на питання, вирішувати завдання або вести проектування в заданій наочній області, в нашому випадку - в менеджменті соціокультурної діяльності.

Залежно від початкового рівня підготовки студента, використовуваної методики викладу матеріалу, необхідного кінцевого рівня навченості, ступеня усвідомленості, ступеня абстракції та необхідного коефіцієнта автоматизації електронного посібника він може бути реалізований у різних варіантах. Посібник може включати лекційний матеріал, задачник, лабораторні роботи, контрольну роботу за модулем (розділом) чи зі всього предмета, електронний довідник, електронний посібник із проектування, ділову гру тощо.

Однією з основних вимог до проектування електронного навчального посібника $є$ його методичне опрацьовування, що включає рішення питання про організацію пізнавальної діяльності студента відповідно до педагогічних закономірностей.

Частина науково-педагогічних працівників вважає, що якщо викладено навчальний матеріал, до нього поставлені питання та дані завдання потрібного на іспиті рівня, то освоєння матеріалу студентом $є$ його особистою справою. Проте такий підхід не може бути виправданий навіть для відмінників, які мають необмежений час для засвоєння навчальної дисципліни. Їм необхідне підкріплення правильності розуміння предмета з боку викладача, причому звернення до викладача відбувається рідше за умови, що електронний посібник пропрацює методично краще. Для основної ж маси студентів необхідна організація їх діяльності відповідно до теорії навчання, особливо під час вивчення складних тем, контролю якості засвоєння знань, алгоритмів, формування умінь, навичок і професійних компетенцій.

Використання електронного посібника в дистанційній технології навчання вимагає приділення особливої уваги контролю регулярності 
й сумлінності роботи студентів із навчальними матеріалами, що забезпечується завдяки моніторингу відвідувань електронного ресурсу та регулярними бесідами (чат, електронна пошта, телефон) між студентом і викладачем за підсумками вивчення тем і розділів.

Узагальнюючи, можна виявити основні методичні вимоги до електронних посібників.

1. Необхідно визначити контингент студентів, тобто для кого навчальний посібник буде створено.

2. Вказати рівень засвоєння знань, який буде визначальним у професійній діяльності майбутнього фахівця. Визначити ступінь абстракції та ступінь усвідомленості менеджменту у соціокультурній діяльності.

3. Розкрити, якою мірою менеджмент у соціокультурній діяльності як навчальна дисципліна відображає рівень розвитку наукових досліджень у цьому напрямі. Визначити перелік навчальних модулів (інших навчальних елементів), що вивчаються.

4. Визначити, який початковий рівень знань необхідний для засвоєння дисципліни в цілому та за окремими навчальними елементами.

5. На підставі взаємозв'язку навчальних елементів між собою та 3 іншими навчальними дисциплінами, виходячи 3 майбутньої професійної діяльності, визначити необхідний підсумковий або кінцевий рівень навченості за окремими навчальними елементами.

6. Побудувати графік взаємозв'язку навчальних елементів і визначити черговість їх викладання.

7. При викладанні кожного розділу доцільно, за можливості, розглянути приклад, який розкриває зміст всіх питань, висвітлених у даному модулі (темі), що забезпечуватиме єдність сприйняття змісту навчального матеріалу.

8. Для кожного параграфа (пункту) вибрати метод викладу: проблемний, інформаційно-рецептивний, дослідницький або евристичний.

9. Підібрати питання за кожною з тем від мінімального рівня їх засвоєння до максимально потрібного.

10. Продумати реакцію комп'ютерної техніки на той або інший варіант відповіді на окреме запитання i/aбо серію запитань для забезпечення послідовного діалогу щодо засвоєння матеріалу теми до заданого рівня.

11. Викласти методичні вимоги до формування завдань, набору практичних робіт, контрольних робіт тощо.

12. Згідно з вимогами провести добір навчального матеріалу до них.

13. Розмістити матеріали на відповідних носіях.

На цій основі уможливлюється системне компонування навчального матеріалу за модулями. Відповідно кожен навчальний модуль доцільно формувати як взаємопов'язану систему, до якої входять: зміст модуля як дидактичної одиниці, теоретичний, практичний і контролюючий розділи. Складові системи передбачають методичний зв'язок, 
взаємодоповнюють і розвивають одна одну. Знання теоретичної частини $\epsilon$ орієнтуючими для виконання практичних завдань, а методи діагностики знань належать як до теоретичного, так і до практичного розділів.

Зміст модуля являє собою орієнтуючу складову щодо засвоєння навчального матеріалу. Ознайомлюючись із ним, студент, який навчатиметься дистанційно, одержує інформацію щодо очікуваних результатів навчання. Звідси до змісту модуля мають входити:

- перелік теоретичних та прикладних навчальних категорій, що визначають необхідний рівень оволодіння професійним понятійним апаратом;

- анотація модуля, яка орієнтуватиме студента на формування знань, умінь і засадних професійних компетенцій.

Теоретичний розділ являє собою текстово-ілюстраційний матеріал, який складається з тем, що увійшли до навчального модуля. Кожна тема передбачає наявність списку ключових понять, поділ на питання (параграфи), запитання для самоперевірки та завдання для самостійної роботи. Гіпертекстові можливості комп'ютера у цьому разі дозволяють із легкістю здійснювати навігацію по усьому навчальному матеріалу як всередині самої теми, так і матеріалами інших тем, інших навчальних дисциплін, сторонніх інформаційних джерел, словників. При цьому з'являється можливість широкого застосування мультимедійних можливостей, зокрема, можливий перехід до опорного конспекту, виконаного у вигляді мультимедійної презентації; можна використовувати звуковий супровід, анімацію, відео тощо.

Неодмінною складовою теоретичного розділу такої навчальної дисципліни, як менеджмент соціокультурної діяльності, має бути наявність посилань на сторонні інформаційні джерела, де б студенти могли отримати додаткову інформацію. Особливо важливими $є$ посилання на часописи та періодичні видання, в т. ч. розміщені в мережі інтернет, у яких віддзеркалюється найсвіжіша ринкова інформація, оскільки, як відомо, саме інформація про сучасний стан та перспективи ринку змінюється щохвилини. А це, своєю чергою, зумовлює її старіння i, відповідно, неточності й похибки у процесі формування професійних компетенцій.

Засобом узагальнення і систематизації знань теоретичного розділу за кожною із тем модуля виступають запитання для самоперевірки, які, згідно з таксономією Блума, мають забезпечувати досягнення другого рівня, тобто розуміння. Правильно сформульовані запитання уможливлюють негайне повернення до незасвоєного студентом теоретичного навчального матеріалу або до пошуку відповідних даних у сторонніх інформаційних джерелах.

Як додатковий дидактичний засіб для опрацювання теоретичного матеріалу, поточної інформації про стан ринку в соціокультурній сфері, а також засобу для організації самостійної роботи та підготовки до практичного блоку ми пропонуємо робочий зошит. Він ведеться з викорис- 
танням текстового редактора MS Word чи інших (інколи, за бажанням студента, - у простому учнівському зошиті). Записи в такому зошиті робляться студентом за кожною із тем, взятих до вивчення.

Як показує практика, такі зошити часто стають своєрідними базами даних для обміну сучасною інформацією, слугують незамінним засобом викладача для формування практичного блоку, особливо - ситуаційних завдань і кейсів. Цінність робочого зошита проявляється ще й через його придатність для висвітлення студентом власних здобутків i/або набутого досвіду, що є прямою передумовою формування компетентних фахівців. Завдяки інтерактивному навчальному середовищу з'являється можливість обміну цими важливими інформаційними матеріалами між студентами, організовуються дискусії, обговорення тощо.

Типові завдання і відповідні записи, що заносяться до робочого зошита:

- короткі відповіді на запитання для самоперевірки й контролю знань;

- нотатки найбільш важливої інформації з літературних та інших інформаційних джерел;

- аналіз взаємозв'язків, послідовностей, процесів;

- висвітлення особистої точки зору щодо явищ, процесів тощо;

- пропозиція власної моделі, плану, алгоритму тощо;

- розв’язки задач, ситуаційних завдань, кейсів;

- трактування питань, наведення прикладів із позицій особистого (професійного) досвіду;

- розробка власного проекту.

Залежно від цілей вивчення конкретної теми робочий зошит придатний для забезпечення досягнення чотирьох найвищих таксономічних рівнів. Тут відстежується застосування знань, вміння аналізувати, синтезувати та оцінювати явища, процеси тощо. Крім того, він відображає всі п'ять рівнів знань відповідно до підходів, запропонованих Жуковою та Кузнєцовим.

Ведення робочого зошита обов'язково перевіряється й оцінюється викладачем у процесі рубіжного та підсумкового контролю, оскільки саме тут найповніше показано самостійну роботу студента, його вмотивованість, зацікавлення обраною галуззю знань, підготовленість до виконання практичних завдань. Стеження за наповненням робочого зошита дає викладачу змогу робити висновки про процес формування професійних компетенцій студента ще до початку проведення контролю і значно полегшує остаточне оцінювання.

Тестові завдання для самоперевірки - розділ, який забезпечує узагальнення вивченого матеріалу шляхом самостійного проходження студентом тестування за кожною із тем модуля. У цьому випадку тестові завдання прописуються у спеціальному програмному середовищі 
(у нашому випадку - це програмна оболонка «Hot Potatoes») і розміщуються в мережі інтернет, внутрішніх комп'ютерних мережах навчального закладу або ж на компакт-диску.

Залежно від завдань і цілей засвоєння навчального матеріалу під час розробки тестових завдань можуть використовуватися різноманітні структури тестів: від тестів із вибираними відповідями до відкритих тестів, тобто таких, що не мають заготовлених варіантів відповіді (Григорчук, 2005, с. 31-35). Практично всі сучасні програмні оболонки для написання тестових завдань дають викладачу змогу розробляти найрізноманітніші їх види.

Основною особливістю тестування для самоперевірки є надання можливості студентам проходити завдання необмежену кількість раз. При цьому нелімітованим має залишатися й час для надання відповіді на завдання. Такі умови потрібні для створення навчального середовища, зорієнтованого на подолання прогалин у засвоєнні навчального матеріалу, концентрації на питаннях і варіантах відповіді, а не на швидкоплинності часу. Інколи доречно застосовувати рандомізацію (випадковий порядок) тестових завдань і варіантів відповіді, що унеможливлює підбір варіантів відповіді шляхом виключення тих варіантів, що були правильними в попередніх запитаннях.

Ще однією важливою ознакою тестових завдань для самоперевірки має бути можливість знаходження правильної відповіді незалежно від кількості попередньо вказаних невірних. Тобто доти, поки студент не вкаже (знайде) правильну відповідь, він має бути на сторінці із запитанням. Цей підхід дозволяє виявляти неправильні відповіді, запам'ятовувати їx і не використовувати під час наступного проходження тестування, що формуватиме знання за принципом «від протилежного».

Специфіка менеджменту в соціокультурній діяльності як практикоорієнтованої навчальної дисципліни передбачає рефлексію студента вже на етапі самоперевірки. Відповідно, до тестових завдань слід відносити питання не лише теоретично-відтворювального характеру, але й питання 3 практичним контекстом. Для вирішення цих завдань, окрім питань на відтворення знань щодо категорій, явищ і процесів, охоплюваних специфікою управління суб'єктами соціокультурної діяльності, тут доцільне застосовування «мікроситуації».

Мікроситуація являє собою невелике ситуаційне завдання, змодельоване на прикладах діяльності організації, держави, фахівця-управлінця, конкурента тощо, при цьому варіантом відповіді $є$ певна категорія, ознака, явище тощо, що безпосередньо вивчається в темі. Наприклад, у процесі вивчення менеджменту в соціокультурній сфері тем, пов'язаних із маркетинговою діяльністю, студент запам'ятовує визначення категорії «протидіючий маркетинг» як комплексу маркетингових заходів, спрямованих на зниження попиту на окремі товари або послуги. В мік- 
роситуації це трактуватиметься так: «Уряд ухвалив рішення про припинення рекламування тютюнових виробів з одночасним зобов'язанням виробників збільшити площу на сигаретних пачках під попередження про шкоду паління. Який вид маркетингу, залежно від співвідношення попиту та пропозиції, застосовано?».

Практичний розділ навчального модуля являє собою ієрархічну структуру, покликану систематизувати отриману навчальну інформацію шляхом ії̈ правильної практичної реалізації. В НМКДДН із вивчення управлінських дисциплін таку структуру доцільно представляти у вигляді, зображеному на рис. 2.

\begin{tabular}{|l|}
\hline 6. Проекти \\
\hline 5. Кейси \\
\hline 4. Розрахункові задачі \\
\hline 3. Мікроситуації \\
\hline $\begin{array}{l}\text { 2. Завдання на відтворення } \\
\text { сукупностей, послідовностей, } \\
\text { процесів }\end{array}$ \\
\hline 1. Завдання на відтворення \\
\hline
\end{tabular}

Аналіз, синтез, оцінювання, творчість

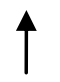

Застосування, знання-навички

Розуміння, знання-вміння

Знання, знання-знайомства, знаннякопії

Puc. 2. Ієрархічна структура практичного розділу Джерело: власна розробка

Fig. 2. Hierarchical structure of the practical section Source: own development

Завдання на відтворення понять передбачають демонстрування студентом ступеня оволодіння навчальною інформацією щодо основних термінів, категорій, означень. Фактично на цьому рівні вдається побачити, наскільки студент володіє термінологічним інструментарієм, ідентифікує окремі значення, розрізняє властивості, виокремлює явища тощо. На рівні відтворення понять віддзеркалюється категоріальне мислення студента, закладаються підвалини професійної лексики, що $\epsilon$ основою подальшого формування фахівця.

На нашу думку, в початкових навчальних модулях (першому модулі) завдання на відтворення понять слід представляти у вигляді тестових завдань із закритими питаннями з однією правильною відповіддю. Такий підхід дає змогу долати прогалини запам'ятовування шляхом наявних порівнянь варіантів відповіді, у такий спосіб мотивуючи студента. Інколи можна використовувати дихотомічні питання з варіантами відповіді типу: «так», «ні», «вірно», «невірно» тощо. 
У наступних навчальних модулях (розділах) ця ж частина може бути представлена у вигляді тестових завдань із відкритими запитаннями, що вимагатиме більш ретельної підготовки студента.

Завдання на відтворення сукупностей, послідовностей, процесів спрямовані на виявлення рівня оволодіння якісно новими знаннями. Тут мають відображатися знання логічних послідовностей, принципів тощо. На цьому рівні студенти демонструють оволодіння знаннями щодо способів і методів оперування базовою специфікою менеджменту в соціокультурній діяльності та знаннями управлінських універсалій і абстракцій.

Для перевірки цього рівня знань найбільш доцільно використовувати тестові завдання з багатоваріантними відповідями. Виконання студентом такого тестового завдання вимагає значних зусиль, оскільки оперування відбувається серед споріднених категорій, а правильно обрана послідовність чи множина вимагає чіткої структуризації. Відповідно, викладач заздалегідь повинен поінформувати студентів про труднощі, забезпечуючи таким чином активізацію процесу вивчення навчального матеріалу.

Мікроситуаиії спрямовані на аналіз розуміння студентом отриманої навчальної інформації та формування знання-вміння. При цьому розуміння демонструється на рівнях інтерпретації та екстраполяції. Інтерпретація проявляється через вирізнення категорій, явищ, процесів, представлених у дещо інший спосіб, ніж у тексті лекції. Екстраполяція - через припущення, висновки, вірогідність тощо.

Розрахункові задачі, якщо вони передбачені змістом навчального модуля та навчальною програмою, покликані показати застосування отриманої навчальної інформації, тобто вказати на вміння студента використовувати вивчений матеріал у нових ситуаціях. У менеджменті кожна розрахункова задача відтворює певний економічний або управлінський процес і за своєю суттю відповідає новій ситуації. Рішення розрахункових задач демонструє набуття знань-навичок шляхом реалізації формалізованих підходів, а отже, забезпечує формування професійних компетенцій для подолання шаблонних проблем. У випадку, коли розрахункові задачі в навчальній програмі не передбачені, таксономічний рівень «застосування» реалізовується у кейсах і проектах.

Кейси - провідна навчальна технологія сучасної бізнес-освіти. Кейс являє собою опис реальної ситуації або послідовності подій, що порушує питання для обговорення або створює проблеми для аналізу та розв'язку. При цьому сам кейс не передбачає аналізу чи висновків, а лише констатує факти й події, викладені у хронологічній послідовності. Кейси виконують ряд важливих функцій, зокрема вони допомагають студентам:

- глибше зрозуміти тему, розвинути уявлення;

- одержати грунт для перевірки теорії, дослідження ідей, виявлення закономірностей, взаємозв'язків, формулювання гіпотез; 
- розвивати й застосовувати аналітичне та стратегічне мислення, вміння вирішувати проблеми та робити раціональні висновки;

- удосконалювати комунікаційні навички;

- пробуджувати інтерес, цікавість, мислення та дискусію;

- одержувати додаткову інформацію, поглиблювати знання;

- переконуватися у поглядах;

- прив'язувати теоретичні знання до ринкових реалій, перетворювати абстрактні знання у цінності та вміння студента (Гапотченко, 2004).

На практиці ситуаційні завдання сприяють реалізації трьох таксономічних рівнів: застосування, аналіз і синтез.

Так само, як і в розрахункових задачах, кейси мають показати застосування отриманої навчальної інформації, вказуючи на вміння студента використовувати вивчений матеріал у нових, взятих до аналізу ситуаціях. Водночас вони спонукають студента користуватися принципами; законами; робити узагальнення, висновки, користуватися відповідними процедурами, методами, теоріями.

Рівень аналізу, згідно із поставленими завданнями, передбачає реалізацію трьох можливих підрівнів:

- аналіз елементів, у ході якого студенти вирізняють елементи, класифікують їх, відносять до певних категорій тощо;

- аналіз взаємозв'язків, що передбачає роботу студентів над протиставленням і порівнянням аргументів, переваг, недоліків причиннонаслідкових зв'язків тощо;

- аналіз організаційних принципів, за допомогою якого студенти аналізують точки зору, тенденції, структури, ієрархію тощо.

На рівні синтезу студент, відповідно до завдання кейсу, формує власне повідомлення, створюючи відповідні структури або видозмінюючи наявні; розробляє план, формує цілі, специфікації тощо; формулює висновки, концепції, розробляє схеми, графіки, висуває гіпотези.

Розробка проекту, який здійснюється на основі принципів пізнавального проектування, являє собою завершальний етап практичного блоку НМКДДН. Використовуване нами пізнавальне проектування, описане різними дослідниками, передбачає вирішення відкритих завдань, що не обмежує студента у виборі засобів та інструментів. Сутність цієї навчальної технології базується на зміні класичної дидактичної схеми на систему «відкриттів» і на реалізації творчих ініціатив (Дзегеленок, 1991; Хуторской, 2000).

На рис. 3 відображено перехід від класичного дидактичного трикутника (а) до трикутника «відкриттів» (б), який активно застосовується в сучасних інноваційних педагогічних технологіях провідних навчальних закладів світу.

Під «відкриттям» ми розуміємо розроблення розгорнутого плану або проекту, що наділений певним ступенем новизни за обов'язкової 
наявності корисних властивостей i/aбо придатності до негайної реалізації в управлінській діяльності.

Очевидно, що навчальний процес не виключає суб'єктивного сприйняття студентом новизни, який, розробляючи проект, вирішує своє нелегке відкрите завдання. Спільність відкритих завдань полягає в їх проектній спрямованості: потрібно побачити, знайти, відкрити, виявити щось нове, а в ідеалі раніше невідоме рішення. Проте це слід робити осмислено, спираючись на сформоване знання. Набуття останнього має пізнавальний характер, що є аргументом на користь пізнавального проектування.

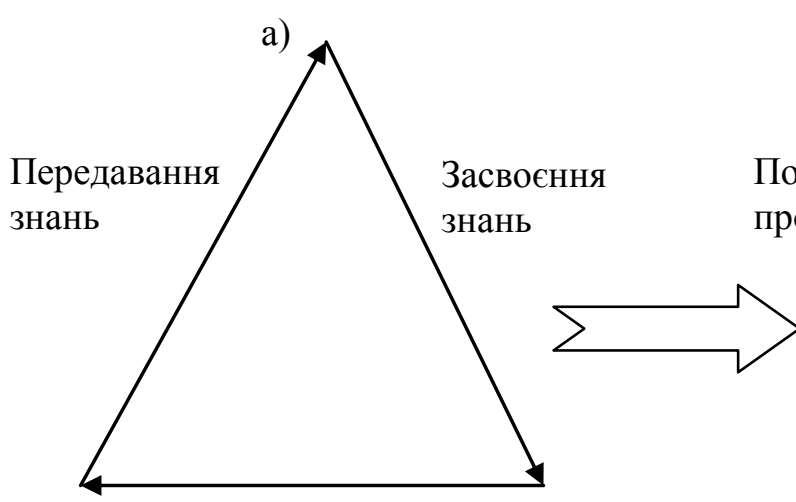

Перевірка рівня засвоєння знань б)

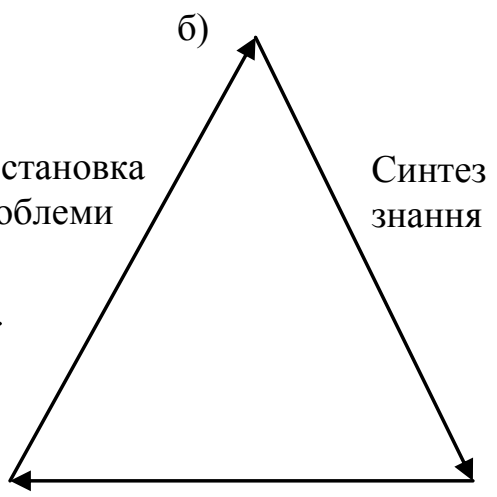

Відкриття нового

Рис. 3. Перехід до навчальної технології «відкриттів» Джерело: розроблено на основі (Дзегеленок, 1991)

Fig. 3. Going to the educational technology of "discoveries" Source: developed on the basis of (Dzegelenok, 1991)

Можливість реалізації переходу, представленого на рис. 3, визначається уточненням сутності поняття відкритого завдання, під яким ми розумітимемо формальну конструкцію, спрямовану на творення шуканого знання у вигляді певної причинно-наслідкової закономірності вдалого рішення через індуктивне узагальнення активно поповнюваної бази чинників-прикладів, сприятливих і несприятливих об'єктів - варіантів реалізації певного проекту в конкретному виді управлінської діяльності.

Середовище об'єктів визначається пошуковим простором, який нагадує собою набір іменних змінних, що характеризують властивості даних об'єктів або проектів.

Наприклад, середовище об'єктів артистичної агенції, яка діє на засадах концепції маркетингу, - велика кількість всіляких різножанрових концертів, а сутнісна змінна відповідає концерту того артиста, що відвідують глядачі. Тоді значення цієї змінної - імена тих артистів, відвідування концертів яких забезпечує агенція. Зрозуміло, що номенкла- 
тура продуктів, пропонованих артистичною агенцією, характеризується багатьма іншими змінними (сервіс, шоу-мерчандайзинг, харчування тощо). Таким чином, пошуковий простір може сягнути великої розмірності кілька десятків, а то й понад сотню іменних змінних.

Тут ми абстрагуємося від способу розмежування об'єктів на сприятливі та несприятливі, вважаючи, що існує певне правило якісної оцінки об’єктів. Не виключено, що правило якісної оцінки - це думка експерта, до якої висувається мінімум вимог щодо кількості градацій в оцінці об’єктів. Однак існує проблема. Вихідна база фактів за кількістю «успіхів» і «невдач», як правило, не є великою. Тому індуктивно виведене значення може виявитися недостовірним.

Ключовим моментом у реалізації даної технології є активне поповнення бази чинників-прикладів шляхом висунення емпіричних гіпотез. Гіпотези - це альтернативи (у нашому прикладі - варіант концертних програм), що вимагають експериментальної перевірки. Вони потрібні для перевірки поточного або заздалегідь сформованого знання щодо його узгодження з практикою.

Експериментальна перевірка гіпотез зводиться до їх оцінювання за допомогою правила якісної оцінки. Зазначимо, що гіпотези бувають позитивні та негативні залежно від знаку «+» або «-», визначуваного поточним знанням. Цілком можливо, що позитивна гіпотеза отримає за правилом якісної оцінки оцінку «невдача», а негативна гіпотеза - оцінку «успіх». Це означатиме, що виявлена суперечність у відповідності поточного знання до практики управління. Але так чи інакше, в результаті оцінки висунутих гіпотез поточна база чинників-прикладів поповнюється.

Наступний крок - формування подальшого уточнення шуканого знання. Умова припинення роботи - відсутність гіпотез. Самі ж гіпотези висуваються згідно з критерієм повноти перевірки шуканого знання або закономірності «успіху». Геометрично ця закономірність являє собою межу розділення всієї сукупності об'єктів (а не їі частини у вигляді початкової бази чинників) на «успіхи» та «невдачі».

Стратегія висунення гіпотез заснована на виявленні й дослідженні тільки цієї межі, а не всього пошукового простору. В результаті різко скорочується кількість висунутих гіпотез або питань до експерта (викладача) при одночасному підвищенні достовірності шуканого знання.

3 використанням цієї технології студент:

1) фіксує пошуковий простір;

2) задає початкову базу фактів;

3) оцінює гіпотези за правилом якісної оцінки.

У такий спосіб студент практично самостійно формує відкрите завдання.

Як показує практика, найбільша трудомісткість, покладена на студента, стосується розрахунків і забезпечення логічної функції, що полягає у синтезі поточного та шуканого знання, виявлення головних чинників та висування гіпотез. 
На нашу думку, такий підхід заслуговує на увагу в силу наявності ряду позитивних ознак.

1. Кожне значення певної іменної змінної автоматично набуває деякої ваги. За величиною цієї ваги можна судити про ступінь впливу даного знання, а в цілому завдяки іменній змінній, яка характеризує властивості сукупності об'єктів, що вивчається, на узагальнений показник якості у вигляді правила якісної оцінки.

2. За величиною значень закономірності «успіху» можна оцінити раніше «незнайомий» об'єкт, якщо його властивості визначаються пошуковим простором.

3. Можна розподілити всі об'єкти в контексті - «краще-гірше» згідно з обумовленим узагальненим показником якості.

4. Неважко знайти краще рішення, що посідає тепер перше місце у зваженому середовищі вивчених об'єктів. Якщо це рішення не належить до кінцевої бази чинників-прикладів, накопичених студентом, то воно набуває статусу «відкриття».

5. Слід зазначити й таку можливість, як «відкриття» за умови оволодіння визначеними властивостями пізнаваного середовища об'єктів. Ці властивості можуть, зокрема, відображати деякі характеристики зовнішнього середовища, що впливають на існування можливих об'єктів. Отриманий результат нагадує рішення оптимізаційної задачі, коли фіксуються конкретні значення ряду змінних. Вказана можливість, особливо коли отримувані «відкриття» узалежнюються конкретними властивостями зовнішнього середовища, досягається за рахунок прояву нелінійності в шуканому знанні.

Ця технологія демонструє свою придатність не лише на рівні індивідуальної творчості студента, вона може бути реалізована в моделі колективних рішень, здатність до яких є особливо важливою для фахівцівуправлінців. Серед студентів, які використовують дистанційну форму навчання, нерідко зустрічаються співробітники, які у такий спосіб спільно можуть вирішувати покладені на них службові завдання.

I, нарешті, слід згадати й про широко культивовані у світі автоматизовані банки відкритих завдань. Фактично тут йдеться про реалізацію метазнань, коли вмістом указаного банку є впорядкована сукупність вже здобутих знань. За використання такої технології перед групою студентів може ставитися надзавдання: добути знання, що перевершують знання та досвід попередників.

Контролюючий етап являє собою органічне завершення практичного блоку навчального модуля (розділу). Контроль успішності студентів 3 урахуванням поточного й підсумкового оцінювання здійснюється у відповідності до тематичного та календарного планів, де зазначено види і терміни контролю. Для обліку та реєстрації показників успішності використовується рейтингова відомість успішності студентів. 
Кожний модуль (розділ) включає бал оцінки поточної самостійної роботи студента, що ведеться ним у робочому зошиті з навчальної дисципліни і де відображаються результати виконання завдань, винесених на самостійну роботу. Рейтинговий бал за самостійну роботу встановлюється як середнє арифметичне з усіх позитивних і негативних оцінок, встановлених за 4-бальною шкалою, отриманих за проведену самостійну роботу за визначеним навчальним модулем (табл. 1, 2; рис. 4).

Рейтингові бали отримує студент і за активну участь у лекційних заняттях, якщо такі передбачені навчальним планом.

Підсумкова контрольна робота, що є завершальним етапом вивчення матеріалу модуля, передбачає використання тестових завдань; кейсів i/aбо розрахункових задач; завдань, спрямованих на відтворення знань щодо основних засад, категорій і процесів управління.

Тестування (в табл. 1, 2 «Тести») здійснюється в режимі комп’ютерної діагностики або за допомогою друкованих завдань, занесених до контрольної роботи. Оцінювання тестів проводиться за власною методикою з приведенням підсумку до встановленої в рейтинговій шкалі балів.

Розрахункові, ситуаційні задачі, кейси, проекти (в табл. 1, 2 «Задачі») заносяться до завдань контрольної роботи й оцінюються за ступенем правильності виконання та представлення результатів. Найвищий бал відповідає правильній, повній і обгрунтованій відповіді.

Завдання, спрямовані на відтворення знань (в табл. 1, 2 «Теорія»), заносяться окремим питанням до контрольної роботи й оцінюються за рівнем трактування висунутих положень. Відповідь уважатиметься неповною, якщо студент не представить особистого бачення проблеми, не змоделює відповідну ситуацію або не наведе певні приклади з практики діяльності підприємницьких структур чи інших організацій.

Заходи з підсумкового контролю за модулем (розділом) проводяться лише по завершенню вивчення навчального матеріалу даного модуля. При цьому критичній оцінці мають піддаватися всі зазначені елементи.

За умови наявності більшої кількості модулів здійснюється перерахунок максимальної кількості балів у бік їх зменшення з урахуванням того, що підсумковий рейтинговий бал має дорівнювати 100. При цьому отримані рейтингові бали можуть переводитися в європейську оцінку ECTS.

Вказаний підхід уможливлює розробку структури рейтингової відомості успішності, яка враховуватиме суму балів за навчальними модулями. До рейтингової відомості успішності можуть заноситися й штрафні бали, які відображають порушення пунктуальності студента щодо виконання календарного плану, несвоєчасність надання для перевірки виконаних робіт тощо. Зазвичай сума цих балів не має перевищувати 10.

Підсумковий контроль може здійснюватися у кілька способів. По-перше, це проведення традиційного іспиту (заліку) за безпосередньої 
участі викладача та студента. На нашу думку, такий підхід є найкращим, оскільки забезпечує пряму комунікацію і дозволяє отримати висновки як щодо набутих студентом компетенцій, так і щодо якості самого процесу дистанційного навчання. У цьому випадку розрахунок рейтингових балів за видами поточного контролю передбачатиме вдвічі менші коефіцієнти (вартості) за кожним із видів. Тоді сума рейтингових балів становитиме 50, і така ж сума буде віднесена на проведення іспиту (заліку).

Табл. 1. Розрахунок рейтингових балів за видами поточного контролю (Навчальний модуль або розділ 1)

Tab. 1. Calculation of rating points by types of current control (Training module or section 1)

\begin{tabular}{|c|c|c|c|c|c|}
\hline $\begin{array}{c}\text { № } \\
\Pi / \Pi\end{array}$ & \multicolumn{2}{|c|}{ Вид діяльності } & $\begin{array}{c}\text { Коефіцієнт } \\
\text { (вартість) виду }\end{array}$ & $\begin{array}{c}\text { Кількість } \\
\text { робіт }\end{array}$ & Результат \\
\hline 1. & \multicolumn{2}{|c|}{ Лекційні заняття } & 2 & 4 & 8 \\
\hline 2. & \multicolumn{2}{|c|}{ Самостійна робота } & 3 & 4 & 12 \\
\hline \multirow{3}{*}{3.} & \multirow{3}{*}{ 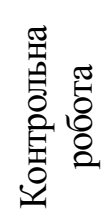 } & Тести & 5 & 1 & 5 \\
\hline & & Задачі & 5 & 1 & 5 \\
\hline & & Теорія & 10 & 1 & 10 \\
\hline
\end{tabular}

Джерело: власна розробка

Source: own development

Табл. 2. Розрахунок рейтингових балів за видами поточного контролю (Навчальний модуль або розділ 2)

Tab. 2. Calculation of rating points by types of current control (Training module or section 2)

\begin{tabular}{|c|c|c|c|c|c|}
\hline $\begin{array}{l}\text { № } \\
\text { П/П }\end{array}$ & \multicolumn{2}{|c|}{ Вид діяльності } & $\begin{array}{c}\text { Коефіцієнт } \\
\text { (вартість) виду }\end{array}$ & $\begin{array}{l}\text { Кількість } \\
\text { робіт }\end{array}$ & Результат \\
\hline 1. & \multicolumn{2}{|c|}{ Лекційні заняття } & 2 & 4 & 8 \\
\hline 2. & \multicolumn{2}{|c|}{ Самостійна робота } & 5 & 4 & 20 \\
\hline \multirow{3}{*}{3.} & \multirow{3}{*}{ 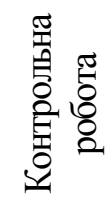 } & Тести & 10 & 1 & 10 \\
\hline & & Задачі & 12 & 1 & 12 \\
\hline & & Теорія & 10 & 1 & 10 \\
\hline \multicolumn{5}{|c|}{ Поточний рейтинговий бал } & 60 \\
\hline \multicolumn{5}{|c|}{$\begin{array}{l}\text { Нормований підсумковий рейтинговий бал } \\
\text { (сума результатів за модулями } 1 \text { і 2) }\end{array}$} & 100 \\
\hline
\end{tabular}

Джерело: власна розробка

Source: own development 


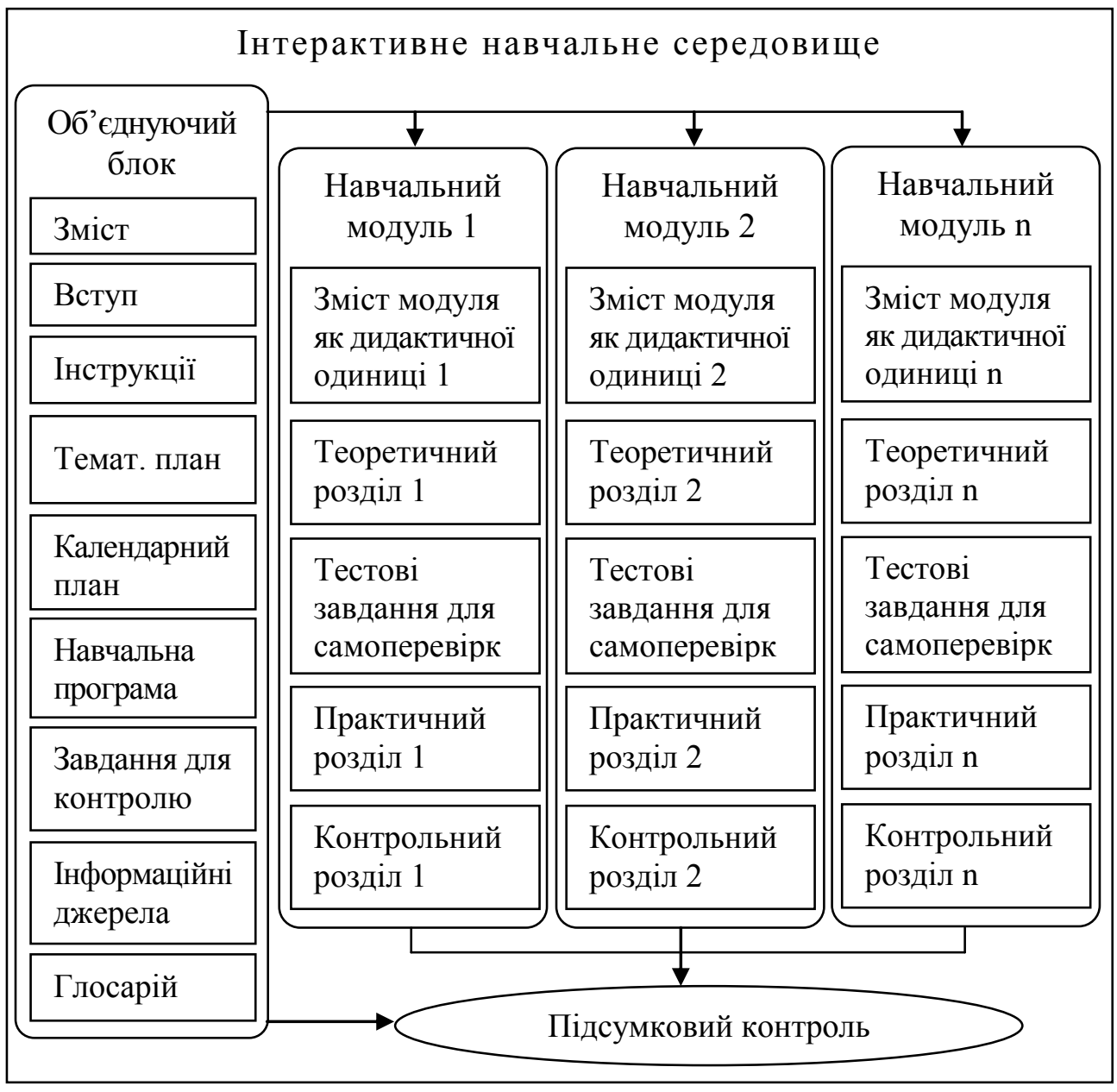

Puc. 4. Модель навчально-методичного комплексу для дистанційного навчання Джерело: власна розробка

Fig. 4. The model of the teaching-methodical complex for distance learning

Source: own development

По-друге, оцінка за іспит (залік) під час підсумкового контролю виставляється на основі суми одержаних рейтингових балів. Причому це може відбуватися або зі згоди студента, або ж встановлюватися як норма ще на початку навчального процесу. За таких умов змін щодо розрахунку рейтингових балів не потрібно.

По-третє, проведення письмового іспиту в режимі online, лімітованого за часом. У цьому випадку завдання для іспиту з'являються в мережі в конкретний, попередньо обумовлений час. Студент повинен виконати його впродовж двох годин і надіслати викладачеві. Затримки караються штрафними балами. За таких умов також необхідно здійснити перерахунок рейтингових балів. 
По-четверте, проведення усного іспиту (заліку) в режимі телеконференції. Такий підхід споріднений із першим, однак, очевидно, його застосування цілком залежить від рівня технічного оснащення робочих місць як викладача, так і студента.

По-п'яте, іспит або залік може проводитися у вигляді комплексного тестування за всією дисципліною з використанням різнопланових тестових завдань з обмеженим часом на відповіді. Таке тестування може здійснюватися в умовах аудиторії на паперових носіях або з використанням комп'ютера, а також у режимі online.

По-шосте, проведення іспиту (заліку) шляхом використання окремих елементів різних підходів.

У цілому, вибір форми підсумкового контролю визначається специфікою навчального закладу в узгодженні з можливостями науковопедагогічного працівника та студентів, що дозволяє забезпечити додатковий рівень гнучкості. Однак умови сьогодення нам все більш активно вказують на те, що в недалекому майбутньому контроль знань також перейде в дистанційну форму, оскільки доводити свою компетентність професіоналу слід буде за вимогою, зумовленою конкретними обставинами, безвідносно до часу, простору чи спеціально означених обставин.

Розглянуті вище складові одиниці комплексу дають змогу виявити між ними системний зв'язок і представити його у вигляді моделі НМКДДН (рис. 4).

Вказана модель дає змогу найбільш повно представити комплекс матеріалів навчальної дисципліни й забезпечити системний підхід до оволодіння необхідними знаннями. Практичний і контрольний розділи сприяють формуванню умінь та навичок, які в синтезі з досвідом і завдяки інтерактивності НМКДДН формують необхідні професійні компетенції.

\section{4. Висновки та обговорення результатів Conclusions and discussion of results}

Результати проведеного дослідження дають змогу стверджувати, що розвиток інформаційно-комунікаційних технологій вказує на важливість дистанційного навчання у процесі підготовки менеджерів соціокультурної діяльності, а це дає можливість дійти таких висновків.

1. Освітній простір формування запитаного професіонала вимагає створення умов для одержання актуальних знань в будь-яких умовах безвідносно до місця, часу та форми надання освітніх послуг. Найкращим засобом логістики запитаних сьогодні знань $є$ дистанційне навчання.

2. Первинною ланкою забезпечення надання необхідних знань у процесі дистанційного навчання є науково-педагогічний працівник, який формує адекватний для дистанційного навчання навчально-методичний комплекс конкретної управлінської дисципліни. 
3. Досягнення запланованих якісних параметрів отримання навчальної інформації напряму пов'язане як зі структурою розділів навчальнометодичного комплексу, так і з часом виконання навчальних завдань, глибиною розкриття їх змісту, а також належного подання набутого студентом досвіду як значимої складової у професійній підготовці менеджера соціокультурної діяльності.

Наукова новизна одержаних результатів полягає у тому, що в дослідженні вперше висунуто структуру навчально-методичного комплексу навчальної дисципліни з урахуванням специфіки діяльності менеджера соціокультурної сфери. При цьому одержали подальший розвиток рішення щодо застосування модульної системи у професійній підготовці фахівців-управлінців, що діятимуть у сфері культури та мистецтв.

Практичне значення виявляється в можливостях застосування отриманого досвіду в процесі підготовки фахівців різних галузей господарювання, а особливо менеджерів сфери послуг. У той же час окремі позиції можуть бути реалізованими і в інших секторах господарювання.

Перспективи подальших наукових розвідок знайдуть своє втілення в розробці окремих методик, базованих на щільній взаємодії практичного досвіду діяльності в соціокультурній сфері та належній адаптації сучасних педагогічних технологій, спрямованих на формування запитаного, кваліфікованого фахівця.

\section{Література}

Андрианова Г. А. Принципы создания учебного модуля для личностноориентированного дистанционного курса. Эйдос. 2004. Апрель. URL: http://www.eidos.ru/journal/2004/1104.htm (дата звернення : 12.02.2019).

Богачков Ю. Вимірювання навчальних досягнень за допомогою інтернеттехнологій. Комп 'ютер у школі та сім'ї. 2004. № 2. С. 11-13.

Гапотченко К. В. Інтерактивні методи викладання бізнес-дисциплін. Київ : УАЗТ, 2004. $224 \mathrm{c}$.

Григорчук Т. В. Використання тестів у дистанційному навчанні. Вісник НТУ «Київський політехнічний інститут». 2005. № 3. С. 31-35.

Григорчук Т. В., Гушулей А. М. Концептуальна модель інтерактивного підручника. Актуальні проблеми навчання та виховання людей з особливими потребами. Київ : Університет «Україна», 2004. С. 411-416.

Григорчук Т. Інтерактивні методи навчання у сучасній системі освітніх послуг. Педагогічні інновачії. 2004. Вип. 8. С. 59-66.

Григорчук Т., Олійник А. Комунікативні та інтерактивні компоненти електронного підручника як чинники формування знань студентів. Вища освіта України. 2005. № 3 (17). С. 74-80.

Дзегеленок И. И. Открытые задачи поискового проектирования. Москва : МЭИ, 1991. $66 \mathrm{c.}$

Жукова Р. Ф., Кузнецов Ю. В. Активные методы обучения в концепции перестройки учебного процесса. Активные методы обучения. Ленинград : ЛГПИ им. А. И. Герцена, 1989. С. 5-13. 
Кесаманлы Ф. П. Учебные модули как активный метод обучения. Активные методы обучения в системе подготовки спещиалистов и руководителей. Ленинград : ЛГПИ им. А. И. Герцена, 1989. С. 121-123.

Кухаренко В. М. Використання вебінару в навчальному процесі. Комп'ютер у школі та сім'ї. 2011. № 2. С. 12-16.

Левшин М. Особистісна зорієнтованість дидактико-методичних комплексів для ВНЗ. Вища освіта Украӥни. 2005. № 2. С. 99-105.

Малафіїк I. В. Дидактика. Київ : Кондор, 2005. 397 с.

Морзе Н. Як навчати вчителів, щоб комп'ютерні технології перестали бути дивом на уроці. Післядипломна освіта. 2005. № 2. С. 25-32.

Олійник В. В. Щодо впровадження дистанційного навчання в післядипломній педагогічній освіті. Післядипломна освіта. 2007. № 1. С. 43-46.

Хуторской А. В. Развитие одаренности школьников. Методика продуктивного обучения. Москва : ВЛАДОС, 2000. 320 с.

Bender R. M. Creating Communities on the Internet: Electronic Discussion List in the Classroom. Computers in Libraries. 1995. Vol. 15. P. 38-43.

Hansen D. E. Knowledge Transfer in Online Learning Environments. Journal of Marketing Education. 2008. Vol. 30. P. 93-105.

Harman L. Teaching Partnering Strategies through the Client-Based Project Approach. Marketing Education Review. 2009. Vol. 19. P. 49-55.

Kearsley G. The Effectiveness and Impact of Online Learning in Graduate Education. Educational Technology. 1995. November-December. P. 37-42.

Willis B. Distance Education at a Glance, Guide \#7. URL: http://www.uidacho. edu/eo/index.html (дата звернення : 12.02.2019).

Стаття надійшла до редакції 12.02.2019

\section{References}

Andrianova, G. A. (2004, April). Printsipy sozdaniya uchebnogo modulya dlya lichnostno-oriyentirovannogo distantsionnogo kursa [Principles of creating a training module for a student-centered distance course]. Eydos [Eidos]. Retrieved from: http://www.eidos. ru/journal/2004/1104.htm (in Russ.).

Bender, R. M. (1995). Creating Communities on the Internet: Electronic Discussion List in the Classroom. Computers in Libraries, 15, 38-43.

Bohachkov, Yu. (2004). Vymiryuvannya navchalnykh dosyahnen za dopomohoyu Internet-tekhnolohiy [Measuring learning achievements using Internet technologies]. Komp'yuter u shkoli ta sim'yi [Computer at school and family], 2, 11-13 (in Ukr.).

Dzegelenok, I. I. (1991). Otkrytyye zadachi poiskovogo proyektirovaniya [Open problems of search design]. Moscow: MEI (in Russ.).

Hansen, D. E. (2008). Knowledge Transfer in Online Learning Environments. Journal of Marketing Education, 30, 93-105.

Hapotchenko, K. V. (2004). Interaktyvni metody vykladannya biznes-dystsyplin [Interactive methods of teaching business disciplines]. Kyiv: UAZT (in Ukr.).

Harman, L. (2009). Teaching Partnering Strategies through the Client-Based Project Approach. Marketing Education Review, 19, 49-55. 
Hryhorchuk, T. (2004). Interaktyvni metody navchannya u suchasniy systemi osvitnikh posluh [Interactive teaching methods in the modern system of educational services]. Pedahohichni innovatsiyi [Pedagogical innovations], 8, 59-66 (in Ukr.).

Hryhorchuk, T. V. (2005). Vykorystannya testiv u dystantsiynomu navchanni [Use of tests in distance learning]. Visnyk NTU «Kyyivskyy politekhnichnyy instytut» [Bulletin of the NTU "Kyiv Polytechnic Institute"], 3, 31-35 (in Ukr.).

Hryhorchuk, T. V., \& Hushuley A. M. (2004). Kontseptualna model interaktyvnoho pidruchnyka [Conceptual model of interactive textbook]. Aktualni problemy navchannya ta vykhovannya lyudey [Actual problems of education and upbringing], 411-416 (in Ukr.).

Hryhorchuk, T., \& Oliynyk, A. (2005). Komunikatyvni ta interaktyvni komponenty elektronnoho pidruchnyka yak chynnyky formuvannya znan studentiv [Communication and interactive components of the electronic textbook as factors of students' knowledge formation]. Vyshcha osvita Ukrayiny [Higher education of Ukraine], 3 (17), 74-80 (in Ukr.).

Kearsley, G. (1995, November-December). The Effectiveness and Impact of Online Learning in Graduate Education. Educational Technology, 37-42.

Kesamanly, F. P. (1989). Uchebnyye moduli kak aktivnyy metod obucheniya [Educational modules as an active method of teaching]. Aktivnyye metody obucheniya $v$ sisteme podgotovki spetsialistov $i$ rukovoditeley [Active teaching methods in the system of training specialists and managers]. Leningrad: LSPI named A.I. Gertsen, 121-123 (in Russ.).

Khutorskoy, A. V. (2000). Razvitiye odarennosti shkol'nikov. Metodika produktivnogo obucheniya [The development of gifted students. Methods of productive learning]. Moscow: VLADOS (in Russ.).

Kukharenko, V. M. (2011). Vykorystannya vebinaru v navchalnomu protsesi [Using webinar in the classroom]. Komp'yuter u shkoli ta sim'yi [Computer at school and family], 2, 12-16 (in Ukr.).

Levshyn, M. (2005). Osobystisna zoriyentovanist dydaktyko-metodychnykh kompleksiv dlya VNZ [Personality orientation of didactic-methodical complexes for higher educational institutions]. Vyshcha osvita Ukrayiny [Higher Education in Ukraine], 2, 99-105 (in Ukr.).

Malafiyik, I. V. (2005). Dydaktyka [Didactics]. Kyyiv : Kondor (in Ukr.).

Morze, N. (2005). Yak navchaty vchyteliv, shchob komp'yuterni tekhnolohiyi perestaly buty dyvom na urotsi [How to teach teachers to stop computer technology from being a miracle in a classroom]. Pislyadyplomna osvita [Postgraduate education], 2, 25-32 (in Ukr.).

Oliynyk, V. V. (2007). Shchodo vprovadzhennya dystantsiynoho navchannya v pislyadyplomniy pedahohichniy osviti [As for the introduction of distance learning in postgraduate pedagogical education]. Pislyadyplomna osvita [Postgraduate education], 1, 43-46 (in Ukr.).

Willis, B. (1997). Distance Education at a Glance, Guide \#7. Retrieved from http: http://www.uidacho.edu/eo/index.html.

Zhukova, R. F., \& Kuznetsov, Yu. V. (1989) Aktivnyye metody obucheniya v kontseptsii perestroyki uchebnogo protsessa [Active teaching methods]. Aktivnyye metody obucheniya $v$ sisteme podgotovki spetsialistov i rukovoditeley [Active teaching]. Leningrad: LSPI named A.I. Gertsen, 5-13 (in Russ.).

Received 12.02.2019 